\title{
EDITORIAL
}

\section{Reflexões sobre a pesquisa qualitativa no campo da comunicação}

\author{
Reflections on qualitative research in the field of communication
}

\author{
Ronaldo Linares, Universidade Tiradentes \\ nuneslinhares.ronaldo8@gmail.com
}

António Pedro Costa, Universidade de Aveiro

pcosta@ludomedia.pt

DOI: 10.12795/Ambitos.2019.i44.17

Mesmo antes do surgimento do alfabeto, o homem já construía suas narrativas mediados por outras linguagens midiáticas, como por exemplo, as imagens. Mesmo antes dos FakNews que hoje intervém na concepção de verdade e questionando os princípios de construção da informação, presente cada vez mais, como um espirito nefasto pairando e pousando no mundo digital, as estratégias de marketing estabelecidas, as informações impressas nos jornais franceses durante a revolução que criou os direitos do homem e do cidadão, principalmente os Moniteur patriote («Monitor Patriota»), posteriormente conhecido como L'Ami du peuple («O Amigo do Povo»).

O jornal de Marat, usava de informações e narrativas de ódio para instigar os opositores ao rei, contribuindo para "informar" a sociedade do que ocorria com o rei e a sua rainha, contribuindo para a queda da monarquia na França revolucionaria. Outros tempos, estratégias mais apropriadas para usar a comunicação numa sociedade as pessoas, precisavam do exercício de decodificação de terceiros para codificar os sentidos de sua interpretação sobre a sociedade, as elações de poder e seu próprio lugar sobre o mundo naquele momento/ tempo/lugar. 
No mundo onde a informação, os meio e formas/linguagens de comunica-la e torná-la viva, cotidiana e ubíqua (Santaella, 2013), tem provocado revoluções na cultura, na economia, no poder, enquanto constituição e forma de sustentação do "status quo" do público ao privado, nas formas de aprender com/para/sobre seu grande/pequeno mundo agora globalizado. A comunicação, continua sendo, tal como na antiguidade, a forma mais importante de dialogar com o outro para informar ou manter-se informado sobre as coisas e os meios técnicos de tornaram-se cada vez mais importantes. Como os meios digitais e seus suportes tecnológicos cada vez mais humanos reaproximamos a percepção.

A revolução Industrial trouxe o avanço tecnológico e com ele, principalmente a partir do século $X X$, os meios de comunicação mediado por meios técnicos. Durante toda a primeira metade deste século, emergiram as preocupações sobre como esses meios, seus sistemas, suas narrativas, estratégias e programas influenciavam as "massas", conceito considerado "eficientemente enganoso" por Thompson (1998, p. 30) pois pressupõe uma vasta recepção de milhares e milhões indivíduos passivos e indiferenciados. Proveniente do Paradigma estruturalista, das teorias sociais e psicológicas nascidas na ciência positiva, as pesquisas sobre os meios voltaram sua ênfase para os aspetos quantitativos visto que a linguagem das massas, "nos lembra que o "para quem" de Lasswell deve ser considerado em termos de "quantos" (Briggs \& Burke, 2016, p. 15)

Com o crescimento do capitalismo industrial e tecnológico na segunda metade do século $\mathrm{XX}$, emergiram novas tradições de pensamento, além de críticas a natureza excessivamente positivista do conhecimento científico moderno (Morin, 1982; Santos, 1988) e dos métodos e instrumentos até então empregados para a compreensão das relações humanas e da vida social. A sombra dessa visão, os estudos sobre os meios de comunicação, voltados para a "massa" como uma totalidade sem rosto, destituída de posicionamento crítico e político, esqueceram de que a comunicação mediada é um fenômeno social contextualizado de sua dimensão simbólica e de sua condição de mercadoria dos meios de comunicação (Thompsom, 1998). A revolução ocorre também na perspectiva das pesquisas sobre os sujeitos, a massa, o consumidor, o espectador, prosumidor, entre outras denominações, mais próximos possível do tempo/espaços/meio pesquisado.

Nos escritos de Briggs \& Burke (2016, p. 11), os autores observam que,

O início da idade da televisão, na década de 1950, deu surgimento à comunicação visual e estimulou a emergência de uma teoria interdisciplinar da mídia. Realizaramse estudos nas áreas de economia, história, literatura, arte, ciência política, psicologia, sociologia e antropologia, o que levou à criação de departamentos acadêmicos de comunicação e estudos culturais.

Como podemos notar, as mudanças na mídia tiveram importantes consequências culturais, sociais e políticas. No entanto, foi no final do século XX e início do XXI no campo da pesquisa das ciências humanas e sociais, que podemos notar um avanço considerável quanto as metodologias de abordagens qualitativas. Em relação ao uso dos meios de comunicação na sociedade contemporânea, sob a hegemonia do digital e das redes sociais, esse avanço implica em novas formas de ação e de interação no mundo social, novos tipos de relações 
sociais e novas maneiras de relacionamento do indivíduo com os outros e consigo mesmo (Thompson,1998).

No campo dos estudos de comunicação, após a segunda guerra, desde a Teoria Crítica até os Estudos Culturais, destacamos novas formas de abordagens científicas e metodológicas, novos instrumentos, novas formas de interpretação do significado para os indivíduos e novas características analíticas do relacionamento social produzidas na relação entre os que produzem e recebem e a informação. É um percurso que ao mesmo tempo, amplia as possibilidades de acesso a subjetividade do indivíduo enquanto processo científico de interpretação das mensagens e narrativas midiáticas e, fortalece a construção de um rigor metodológico que assegura a compreensão das práticas midiáticas, de produção, distribuição e recepção, enquanto relações subjetivas socio culturais e políticas.

\section{Referencias}

Asa, B., Burke, P. (2016). Uma história social da mídia: de Gutenberg à internet. Rio de Janeiro: Zahar.

Morin, E. (1982). Ciência com Consciência. Lisboa: Publicações Europa - América.

Santaella, L. (2013). Comunicação ubíqua: repercussões na cultura e na educação. São Paulo: Paulus.

Sousa Santos, B. (1988). Um discurso sobre as Ciências na transição para uma ciência pós-moderna,

Estudos avançados, v.2, n.2, São Paulo, Mai./Ago. p.46-71, Retrieved from http://www. scielo.br/pdf/ea/v2n2/v2n2a07.pdf

Thompson, J. B. (1998). A Mídia e a modernidade: Uma teoria social da mídia. Petrópolis: Vozes. 